Published in final edited form as:

Biol Blood Marrow Transplant. 2012 January ; 18(1 Suppl): S139-S150. doi:10.1016/j.bbmt. 2011.10.005.

\title{
Subsequent Malignant Neoplasms after Hematopoietic Cell Transplantation
}

\author{
Gerard Socié, MD, $\mathbf{P h D}^{1,2}$, K. Scott Baker, MD, $\mathbf{M S}^{3}$, and Smita Bhatia, MD, MPH \\ ${ }^{1}$ Hematology Transplantation, APHP Hospital Saint Louis and University Paris VII Denis Diderot, \\ Paris; France \\ 2INSERM U728 \\ ${ }^{3}$ Clinical Research Division, Fred Hutchinson Cancer Research Center, Seattle, WA \\ ${ }^{4}$ Population Sciences, City of Hope, Duarte, CA
}

\section{Introduction}

Subsequent malignant neoplasms (SMNs) developing after hematopoietic cell transplantation (HCT) are a well-described complication (1-6). The magnitude of risk of SMNs after HCT ranges from 4-fold to 11-fold that of the general population. The estimated actuarial incidence is reported to be $3.5 \%$ at 10 years, increasing to $12.8 \%$ at 15 years among recipients of allogeneic HCT. The differing clinicopathologic characteristics of SMNs preclude assessment of risk factors in aggregate. It has become conventional practice to classify SMNs into three distinct groups (7): (i) myelodysplasia (t-MDS)/acute myeloid leukemia (t-AML); (ii) lymphoma, including lymphoproliferative disorders; and (iii) solid tumors. While t-MDS/AML and lymphoma develop relatively early in the posttransplantation period, secondary solid tumors have a longer latency. The magnitude of risk and associated risk factors for the development of SMNs are summarized in Table 1, and detailed in the sections below.

\section{Magnitude of Risk of Subsequent Malignant Neoplasm}

\section{Therapy-related myelodysplasia/ acute myeloid leukemia}

The cumulative probability of developing t-MDS/t-AML ranges from $1.1 \%$ to $24.3 \%$ at 20 to 43 months after autologous HCT. In patients treated with alkylating agents, t-MDS/tAML usually appears 4 to 7 years after exposure. The majority of patients present with multilineage dysplasia and peripheral cytopenias. There is a high prevalence of abnormalities involving chromosomes $5(-5 / \mathrm{del}[5 \mathrm{q}])$ and 7 (-7/del[7q]). AML secondary to topoisomerase II inhibitors presents as overt leukemia. The latency ranges from 6 months to 5 years, and is associated with balanced translocations involving chromosome bands 11q23 or $21 \mathrm{q} 22$.

\footnotetext{
(c) 2011 The American Society for Blood and Marrow Transplantation. Published by Elsevier Inc. All rights reserved.

Corresponding author: Smita Bhatia, MD, MPH, Associate Director, Population Research, City of Hope Comprehensive Cancer Center, 1500 Duarte Ave, Duarte, CA 91010, 626-471-7321, Fax: 626-301-8983, sbhatia@coh.org.

Publisher's Disclaimer: This is a PDF file of an unedited manuscript that has been accepted for publication. As a service to our customers we are providing this early version of the manuscript. The manuscript will undergo copyediting, typesetting, and review of the resulting proof before it is published in its final citable form. Please note that during the production process errors may be discovered which could affect the content, and all legal disclaimers that apply to the journal pertain.

Financial disclosure : The authors have nothing to disclose.
} 
The common and nonspecific nature of cytopenias after autologous HCT has necessitated the creation of criteria for diagnosing t-MDS/t-AML after HCT. These include (i) significant marrow dysplasia in at least two cell lines, (ii) peripheral cytopenias without alternative explanations, and (iii) blasts in the marrow defined by French-American-British classification (8). Because many patients may not have an increase in blasts, presence of a clonal cytogenetic abnormality in addition to morphologic criteria of dysplasia may aid in making this diagnosis.

An increased risk of t-MDS/t-AML is associated with older age at HCT (1), pretransplantation therapy with alkylating agents, topoisomerase II inhibitors, and radiation therapy (3), use of peripheral blood hematopoietic cells, stem cell mobilization with etoposide, difficult stem cell harvests, conditioning with TBI, number of $\mathrm{CD} 34^{+}$cells infused, and a history of multiple transplants $(1,3,9-11)$.

The diagnosis of t-MDS/t-AML after autologous HCT confers a poor prognosis, with a median survival of 6 months in patients treated with conventional chemotherapy. In fact, tMDS/t-AML is a major cause of nonrelapse mortality in patients undergoing autologous $\operatorname{HCT}(3,12)$. Allogeneic HCT has been attempted with actuarial survival ranging from $0 \%$ to $24 \%$ at 3 years (13). Among t-MDS/t-AML patients with balanced aberrations, 11q23 translocations are an independent adverse risk factor (14). Treatment-related mortality (TRM) and relapse were reported to be $41 \%$ and $27 \%$ at 1 year and $48 \%$ and $31 \%$ at 5 years, respectively in large cohort of patients undergoing allogeneic HCT (15). Disease-free (DFS) and overall survival (OS) were $32 \%$ and $37 \%$ at 1 year and $21 \%$ and $22 \%$ at 5 years, respectively. Age older than 35 years; poor-risk cytogenetics; t-AML not in remission or advanced t-MDS; and donor other than an HLA-identical sibling or a partially or wellmatched unrelated donor had adverse impacts on DFS and OS. Because the poor outcomes of allogeneic transplant for t-MDS/t-AML are related in part to the high risk of TRM, it is important to evaluate the role of reduced intensity conditioning approaches in this setting. Preliminary reports suggest that allogeneic HCT using reduced-intensity conditioning is feasible and may result in improved outcomes.

\section{Post-transplantation lymphoproliferative disorder}

Post-transplantation lymphoproliferative disorder (PTLD) is the most common SMN in the first year after allogeneic T-cell-depleted HCT, and is related to a compromised immune status and EBV infection $(16,17)$. The risk of PTLD is strongly associated with T-cell depletion of the donor marrow, antithymocyte globulin (ATG) use, unrelated or HLA mismatched grafts, presence of acute or chronic GvHD, older age at HCT, and multiple transplants. The cumulative incidence is $0.2 \%$ among patients with no major risk factors, but increased to $1.1 \%, 3.6 \%$, and $8.1 \%$ with 1,2 , and $>3$ risk factors, respectively. The large majority of the PTLDs have a B-cell origin. Therapeutic approaches include B-cell-specific monoclonal antibodies, and cellular therapy. The efficacy of anti-CD20 monoclonal antibody (rituximab) in the treatment of PTLD has been reported. The drug is more efficacious in patients without mass lesions, forming the basis for recommendations to initiate treatment at an early stage, based on increasing EBV load. Because EBV-associated PTLD results from T-cell dysfunction, reconstitution of "at-risk" patients with EBV-specific cytotoxic T-lymphocyte lines reactivated and expanded in vitro has been shown to be efficacious in controlling PTLD, with a decrease in the EBV DNA concentrations and clinical remission.

Late-occurring lymphoma is distinct from the early-occurring PTLD (18), and is associated with extensive chronic GvHD. Hodgkin lymphoma has also been described after HCT (19). Mixed cellularity is the most commonly reported subtype, and most of the cases contain the EBV genome. These cases differ from the EBV-PTLD by the absence of risk factors 
commonly associated with EBV-PTLD, by a later onset ( $>2.5$ years), and a relatively good prognosis.

\section{Solid tumors}

Solid tumors develop after syngeneic, allogeneic, and autologous HCT. The reported cumulative incidence of solid cancers following allogeneic SCT ranges from, $1.2 \%$ to $1.6 \%$ at 5 years, 2.2 to $6.1 \%$ at 10 years and from 3.8 to $14.9 \%$ at 15 years post transplantation (1, $2,4,20-24)$. There is no evidence for any plateau in the incidence rate (4); rather the slope of the curve continues to show a steadily increased incidence with increased follow-up. Radiation is the single most important risk factor for the development of solid tumors. These radiogenic cancers have a long latent period, and the risk is frequently high among patients undergoing irradiation at a young age. Immunologic alterations may predispose patients to SCC of the buccal cavity, particularly in view of the association with chronic GvHD (25). In immunosuppressed patients, oncogenic viruses such as human papillomavirus may contribute to SCC of the skin and buccal mucosa after transplantation (25). Types of solid tumors reported in excess among HCT recipients include melanoma, cancers of the oral cavity and salivary glands, brain, liver, uterine cervix, thyroid, breast, bone, and connective tissue $(2,4)$. Second solid tumors represent an important cause of non-relapse related death in patient who survive more than 2-5 years post transplantation accounting for 5 to $10 \%$ of late deaths (26-30). The sections below describe the magnitude of risk of second solid tumors from single institution studies, as well as large collaborative initiatives.

Single center studies-In the first larger series, analyzing results in 2145 patients transplanted from 1970-1987 in Seattle, Witherspoon et al (7) found 35 new malignancies, including 13 solid tumors. TBI was a significant risk factor when all malignancies were considered. Subsequent analysis of the results in patients with aplastic anemia transplanted in Seattle and at Hospital Saint Louis in Paris $(31,32)$ as well as reports from other American and European centers $(21,29)$ showed that irradiation was a significant risk factor. A combined analysis of results in 700 patients with aplastic anemia transplanted at the Fred Hutchinson Cancer Research Center (FHCRC) or Hospital Saint Louis (32) suggested that in addition to irradiation (relative risk [RR] 3.9) treatment of chronic GvHD with azathioprine $(R R=7.5)$ and older age $(R R=1.1)$ increased the risk of a posttransplantation malignancy. Not surprisingly the highest incidence of malignancy was observed in patients in whom the etiology of marrow failure was Fanconi anemia. Bhatia and colleagues (1) summarized the Minneapolis results: among 2150 patients, 15 developed a solid tumor (8 in 1400 allogeneic and 7 in 750 autologous transplant recipients) for a cumulative probability of $5.6 \%$ at 13 years. Again, irradiation was the major risk factor (RR $6 ; \mathrm{p}=0.008)$. The role of pre-transplant treatment was also examined by Bhatia and coworkers in another study (20), patients who had undergone SCT at the City of Hope National Medical Center between 1976 and 1998 were studied. A retrospective cohort and nested case-control study design were used to evaluate the role of pre-transplantation therapeutic exposures and transplant conditioning regimens. Twenty-nine patients developed solid cancers after BMT, which represents a 2-fold increase in risk compared with a comparable normal population. The estimated cumulative probability for development of a solid cancer was $6.1 \%+/-1.6 \%$ at 10 years. This largely confirms previous results. However, no significant factor emerged from the nested case-control study used to evaluate the role of pre-transplantation therapeutic exposures.

Collaborative studies-The relative paucity of cases rapidly pointed out the critical need for collaborative studies. In an international effort the CIBMTR, the NIH, and the FHCRC in Seattle launched such collaborative studies. In the first one Curtis et al. (2) analyzed results in 19,220 patients (97.2\% allogeneic, $2.8 \%$ syngeneic recipients) transplanted 
between 1964 and 1992 at 235 centers. There were 80 solid tumors for an observed/expected $(\mathrm{O} / \mathrm{E})$ ratio of 2.7. The cumulative incidence of tumors was $2.2 \%$ at 10 years and $6.7 \%$ at 15 years. The risk was increased significantly for melanoma $(\mathrm{O} / \mathrm{E}=5.0)$, cancers of the buccal cavity $(\mathrm{O} / \mathrm{E}=11.1)$, liver $(\mathrm{O} / \mathrm{E}=7.5)$, $\mathrm{CNS}(\mathrm{O} / \mathrm{E}=7.6)$, thyroid $(\mathrm{O} / \mathrm{E}=6.6)$, bone $(\mathrm{O} / \mathrm{E}=$ 13.4), and connective tissue $(\mathrm{O} / \mathrm{E}=8.0)$. The risk was highest for the youngest patients and declined with age ( $\mathrm{p}$ for trend $<0.001$ ). The risk associated with TBI declined if irradiation was given with a fractionation regimen but increased with the total cumulative dose administered.

Since the risk was highest in youngest patients, the NIH/ IBMTR \& FHCRC research group then analyzed a cohort of children transplanted for leukemia (33). A cohort of 3,182 children diagnosed with acute leukemia before the age of 17 years who received allogeneic SCT between 1964 and 1992 at 235 centers was studied. Cumulative risk of solid cancers increased sharply to $11.0 \%$ at 15 years and was highest among children at ages younger than 5 years at transplantation. Thyroid and brain cancers $(n=14)$ accounted for most of the strong age trend; many of these patients received cranial irradiation before HCT.

A case-control study of 183 patients with post-transplantation solid cancers (58 SCCs, 125 non-SCCs) and 501 matched control patients within a cohort of 24,011 patients was conducted (34). Results showed that chronic GVHD and its therapy were strongly related to the risk for SCC; whereas no increase in risk was found for non-SCCs. Major risk factors for the development of SCC were long duration of chronic GVHD therapy; use of azathioprine, particularly when combined with cyclosporine and steroids; and severe chronic GVHD.

Since in the first NIH / IBMTR \& FHCRC study relatively few patients surviving more than 10 years post-SCT were included, we have continued surveillance of these and other SCT survivors to determine whether solid cancer risk changed beyond 10 years after transplantation (4); 189 new cancers were found in 28,874 allogeneic SCT recipients. Average age at transplantation was 27 years, $67 \%$ of patients received TBI as part of their preparative regimen. The cumulative incidence of invasive solid cancers for all patients was $2.2 \% \pm 0.4 \%$ at 10 years, $5.0 \% \pm 1.2 \%$ at 15 years, and $8.1 \% \pm 3.1 \%$ at 20 years. New findings showed that the risk of developing a non-squamous cell carcinoma (non-SCC) following conditioning radiation was highly dependent on age at exposure. Among patients irradiated at ages under 30 years, the relative risk of non-SCC was 9 times that of non irradiated patients, while the comparable risk for older patients was 1.1. Chronic graftversus-host disease and male sex were the main determinants for risk of SCC. Sites with significantly $(\mathrm{p}<0.05)$ increased risks of second cancers after transplantation were oral cavity $(\mathrm{O} / \mathrm{E}=11.6)$, salivary glands $(\mathrm{O} / \mathrm{E}=14.2)$, liver $(\mathrm{O} / \mathrm{E}=6.9)$, skin $(\mathrm{O} / \mathrm{E}=4.2)$, brain $(\mathrm{O} /$ $\mathrm{E}=6.0)$, thyroid $(\mathrm{O} / \mathrm{E}=6.3)$ and bone/connective tissue $(\mathrm{O} / \mathrm{E}=8.4)$. A new finding in this study, not seen in previous reports, is a significantly increased risk of breast cancer among 10 -year survivors $(\mathrm{O} / \mathrm{E}=3.3$ with 5 observed cases $)$.

Finally, risks of secondary solid cancers among allogeneic SCT recipients who receive conditioning without TBI were not well known. We thus evaluated the incidence and risk factors for solid cancers after HCT using high-dose Busulfan-Cyclophosphamide conditioning in 4,318 recipients of first allogeneic HCT for acute myeloid leukemia in first complete remission and chronic myeloid leukemia in first chronic phase $(\mathrm{N}=2,576)(35)$. Our cohort represented 22041 person-years at risk. Sixty-six solid cancers were reported at a median of 6 years after HCT. The cumulative-incidence of solid cancers at 5 and 10 years after HCT was $0.6 \%$ and $1.2 \%$ among acute myeloid leukemia and $0.9 \%$ and $2.4 \%$ among chronic myeloid leukemia patients. In comparison to general population incidence rates, HCT recipients had 1.4-fold higher than expected rate of invasive solid cancers. Recipients of allogeneic HCT using Busulfan and Cyclophosphamide conditioning are at risk for 
developing solid cancers. For the first time an excess risk of lung cancers was found in longterm survivors after SCT.

The magnitude of risk and associated risk factors for some of the more commonly occurring second solid tumors among HCT recipients are detailed below:

Skin cancer-The 20-year cumulative incidence of basal cell carcinoma (BCC) and squamous cell carcinoma (SCC) are reported to be $6.5 \%$ and $3.4 \%$, respectively after allogeneic HCT (25). TBI is a risk factor of BCC particularly among patients younger than 18 years old at HCT. Acute GvHD increased the risk of SCC; and chronic GvHD increased the risk of BCC and SCC (36).

Breast cancer-The 25-year cumulative incidence of breast cancer is reported to be $11 \%$ after allogeneic HCT (5); Allogeneic HCT survivors are at a 2.2-fold increased risk of developing breast cancer, when compared with age- and sex-matched general population. The median latency from HCT to diagnosis of breast cancer is 12.5 years. The incidence is higher among those exposed to TBI (17\%) than among those who did not receive TBI (3\%). The risk is increased among those exposed to TBI at a younger age.

Thyroid Cancer-Cohen et al described the risk of thyroid cancer after HCT. HCT recipients were at a 3.3-fold increased risk of thyroid cancer, when compared with age- and sex-matched general population (6). Age younger than 10 years at HCT, neck radiation, female sex, and chronic GvHD were associated with an increased risk of thyroid cancer. Thyroid cancer developed after a latency of 8.5 years in this cohort, and was associated with an excellent outcome.

\section{Pathogenesis of Subsequent Malignant Neoplasms after Hematopoietic cell Transplantation}

The magnitude of association between specific chemotherapeutic agents or radiation, and SMNs is moderate to large (OR: 3.1 to 15.9), with a clear dose-response relationship adding further biological credibility to this association. The risk of second breast cancer after chest radiation increases in a linear fashion with radiation dose ( $p$ for trend $<0.001)(37,38$ ), as does the risk for second brain tumors, and second sarcomas (39). Literature clearly supports the role of chemotherapy and radiation in the development of SMNs (40), but interindividual variability suggests a role for genetic variation in susceptibility to genotoxic exposures. The risk of SMNs could potentially be modified by mutations in high-penetrance genes that lead to serious genetic diseases e.g., Li-Fraumeni syndrome (41), and Fanconi anemia $(42,43)$. However, attributable risks are expected to be very small because of their extremely low prevalence. The interindividual variability in risk of therapy-related SMNs is more likely related to common polymorphisms in low-penetrance genes that regulate the availability of active drug metabolite, or those responsible for DNA repair. Genetic variation contributes $20 \%$ to $95 \%$ of the variability in cytotoxic drug disposition (44). Polymorphisms in genes involved in drug metabolism and transport are relevant in determining disease-free survival and drug toxicity (45). Variation in DNA repair plays a role in susceptibility to de novo cancer (46-50), and likely modifies SMN risk after exposure to DNA-damaging agents, such as radiation and chemotherapy. Gene-environment interactions may magnify subtle functional differences resulting from genetic variations (51-54).

\section{Drug Metabolism}

Metabolism of genotoxic agents occurs in two phases. Phase I involves activation of substrates into highly reactive electrophilic intermediates that can damage DNA - a reaction 
principally performed by the cytochrome p450 (CYP) family of enzymes. Phase II enzymes (conjugation) function to inactivate genotoxic substrates. The phase II proteins comprise the glutathione S-transferase (GST), NAD(P)H:quinone oxidoreductase-1 (NQO1), and others. The balance between the two sets of enzymes is critical to the cellular response to xenobiotics; e.g., high activity of phase I enzyme and low activity of a phase II enzyme can result in DNA damage from the excess of harmful substrates. Given that these enzymes activate/ detoxify chemotherapeutic agents - their role in the development of SMNs applies mainly to t-MDS/AML. The xenobiotic substrates of CYP proteins include cyclophosphamide, ifosfamide, thiotepa, doxorubicin, and dacarbazine(55). The CYPs transfer singlet oxygen onto their substrates creating highly reactive intermediates which, unless detoxified by phase II enzymes, have a strong ability to damage DNA (56). The expression of these enzymes is highly variable among individuals because of several functionally relevant genetic polymorphisms. GSTs detoxify reactive electrophiles via conjugation to reduced glutathione, preventing damage to DNA. Polymorphisms exist in cytosolic subfamilies: $\mu[\mathrm{M}], \pi[\mathrm{P}), \theta[\mathrm{T}]$, and others. GSTs detoxify doxorubicin, lomustine, busulfan, chlorambucil, cisplatin, cyclophosphamide, melphalan, etc. (57). Quinone oxidoreductase NQO1 uses the cofactors NADH and NADPH to catalyze the electron reduction of its substrates, produces less reactive hydroquinones, and therefore prevents generation of reactive oxygen species and free radicals which may subsequently lead to oxidative damage of cellular components. Allan et al utilized a candidate gene approach to examine associations between polymorphisms in the glutathione S-transferase genes (GSTM1, GSTT1 and GSTP1) and t-MDS/AML (58). A case-control study design was used (80 cases; 420 patients with de novo AML; 1022 healthy controls). Individuals with at least one GSTP1 codon $105 \mathrm{Val}$ allele were significantly over-represented in t-AML cases compared with de novo AML cases ( $\mathrm{OR}=1.81,95 \% \mathrm{CI}, 1.11-2.94)$. Also, relative to de novo AML, the GSTP1 codon 105 allele occurred more often among t-AML patients with prior exposure to chemotherapy $(\mathrm{OR}=2.66,95 \% \mathrm{CI}, 1.39-5.09)$, particularly among those with prior exposure to known GSTP1 substrates $(\mathrm{OR}=4.34,95 \% \mathrm{CI}, 1.43-13.20)$ and not among tAML patients with exposure to radiation alone.

\section{DNA repair}

DNA repair mechanisms protect somatic cells from mutations in tumor suppressor genes and oncogenes that can lead to cancer initiation and progression. An individual's DNA repair capacity appears to be genetically determined (59). A number of DNA repair genes contain polymorphic variants, resulting in large inter-individual variations in DNA repair capacity (59). Even subtle differences in an individual's DNA repair capacity may be important in the presence of large external influences such as chemotherapy or radiotherapy. Individuals with altered DNA repair mechanisms are likely susceptible to the development of genetic instability that drives the process of carcinogenesis as it relates to both chemotherapy-related t-MDS/AML as well as radiation-related solid SMNs.

Mismatch repair (MMR) functions to correct mismatched DNA base pairs that arise as a result of misincorporation errors that have avoided polymerase proofreading during DNA replication (60). Defects in the MMR pathway result in genetic instability or a mutator phenotype, manifested by an elevated rate of spontaneous mutations characterized as multiple replication errors in simple repetitive DNA sequences (microsatellites) functionally identified as microsatellite instability (MSI). Approximately 50\% of t-MDS/ AML patients have MSI, associated with methylation of the MMR family member MLH1 $(61,62)$, low expression of MSH2 (63), or polymorphisms in MSH2 (64-66). The appearance of MMR-deficient, drug-resistant clones during genotoxic treatment for a primary cancer could be a vital factor in SMN susceptibility, particularly because the mutator phenotype (inherent of MMR-deficient cells) would be expected to accelerate the 
accumulation of further mutations and eventually SMN initiation. In addition, loss of MMR may result in deregulation of homologous recombination repair and consequent chromosomal instability (67).

Double-Strand Breaks (DSBs) in DNA may lead to loss of genetic material, resulting in chromosomal aberrations. High levels of DSBs arise following ionizing radiation and chemotherapy exposures. Cellular pathways available to repair DSBs include homologous recombination (HR), nonhomologous end-joining (NHEJ), and single-strand annealing (68). HR uses the second, intact copy of the chromosome as a template to copy the information lost at the DSB site on the damaged chromosome - a high-fidelity process. RAD51 is one of the central proteins in the HR pathway, functioning to bind to DNA and promote ATPdependent homologous pairing and strand transfer reactions (69, 70). RAD51-G-135C polymorphism is significantly over-represented in patients with t-MDS/AML compared with controls (C allele: $\mathrm{OR}=2.7)$ (71). XRCC3 also functions in the HR DSB repair pathway by directly interacting with, and stabilizing $\operatorname{RAD} 51(72,73)$. XRCC3 is a paralog of RAD51, also essential for genetic stability $(74,75)$. The variant XRCC3-241Met allele has been associated with a higher level of DNA adducts compared with cells with the wild type allele, implying aberrant repair (76) and has also been associated with increased levels of chromosome deletions in lymphocytes after exposure to radiation (77). Although XRCC3Thr241Met was not associated with t-MDS/AML ( $\mathrm{OR}=1.4,95 \% \mathrm{CI}, 0.7-2.9$ ), a synergistic effect resulting in an 8-fold increased risk of t-MDS/AML (OR=8.1, 95\% CI, 2.2-29.7) was observed in the presence of XRCC3-241Met and RAD51-135C allele in patients with tMDS/AML compared with controls (71). NHEJ pathway joins broken DNA ends containing very little homology. This process is not always precise and can result in small regions of non-template nucleotides around the site of the DNA break, potentially relevant in MLLtranslocation associated with t-MDS/AML.

Base Excision Repair (BER) pathway corrects individually damaged bases occurring as a result of ionizing radiation and exogenous xenobiotic exposure. The XRCC1 protein plays a central role in the BER pathway and also in the repair of single strand breaks, by acting as a scaffold and recruiting other DNA repair proteins $(78,79)$. The protein also has a BRCA1 C-terminus (BRCT) domain - a characteristic of proteins involved in DNA damage recognition and response. The presence of variant XRCC1-399Gln has been shown to be protective for t-MDS/AML (80), and BCC (81).

Nucleotide Excision Repair (NER) removes structurally unrelated bulky damage induced by radiation and chemotherapy. The NER pathway is linked to transcription, and components of the pathway comprise the basal transcription factor IIH complex (TFIIH), which is required for transcription initiation by RNA polymerase II. One of the genes involved in the NER pathway $(E R C C 2)$ is a member of the TFIIH complex. The polymorphic Gln variant (ERCC2 Lys751Gln) is associated with t-MDS/AML (52).

A proposed mechanism of the pathogenesis of therapy-related SMNs is illustrated in Figure 1. Several studies have attempted to understand the pathogenesis of therapy-related SMNs. These reports encompass both children and adults, treated with conventional therapy, as well as with HCT. They are summarized in the following sections.

Ellis et al utilized a case-control study design (171 cases) and examined the association between patients with t-MDS/AML and 2 common functional p53-pathway variants - the MDM2 SNP309 and the TP53 codon 72 polymorphism (82). Neither polymorphism demonstrated a significant association. However, an interactive effect was detected such that MDM2 TT TP53 Arg/Arg double homozygotes and individuals carrying both a MDM2 G allele and a TP53 Pro allele were at increased risk of chemotherapy-related t-MDS/AML. 
The strengths of the study included the utilization of a discovery ( $\mathrm{n}=80$ case) and replication set ( $\mathrm{n}=91$ cases). However, the investigators utilized healthy controls as a comparison group - thus precluding the ability to assess whether the case-control differences reflected differences in susceptibility to primary disease or t-MDS/AML.

Knight et al utilized a case-control study design to conduct a GWAS in patients who had developed therapy-related leukemia (cases) and healthy controls (83). The discovery set included 80 cases and 150 controls. The relevant findings were replicated in an independent set of 70 cases and 95 controls. The investigators identified 3 SNPs (rs1394384 [OR=0.29, 95\% CI, 0.15-0.56], rs1381392 [OR=2.08, 95\%CI, 1.29-3.35], and rs1199098 [OR=0.46, 95\% CI, 0.27-0.79]) to be associated with t-MDS/AML with chromosome 5/7 abnormalities. rs1394384 is intronic to ACCN1, a gene encoding an amiloride-sensitive cation channel that is a member of the degenerin/ epithelial sodium channel; rs1199098 is in LD with IPMK, which encodes a multikinase that positively regulates the prosurvival AKT kinase and may modulate Wnt/beta-catenin signaling; rs1381392 is not near any known genes, miRNAs, or regulatory elements, although it lies in a region recurrently deleted in lung cancer. Although the investigators were able to confirm findings in an independent replication cohort, the utilization of a non-cancer healthy control group raises concerns about the case-control differences being generated by the genetics of the primary cancer vs. t-MDS/AML.

Best et al performed a GWAS to identify variants associated with radiation-related solid malignancies in survivors of Hodgkin lymphoma (84). They identified two variants at chromosome 6q21 associated with second malignancies. The variants comprise a risk locus associated with decreased basal expression of PRDM1 and impaired induction of the PRDM1 protein after radiation exposure. These data suggest new gene-exposure interaction that may implicate $P R D M 1$ in the etiology of radiation therapy-induced second malignancies.

\section{Burden of Morbidity from Subsequent Malignant Neoplasms after Hematopoietic cell Transplantation}

As indicated in the sections above, SMNs are a major factor contributing to the long-term morbidity and mortality experienced by survivors after HCT. In data reported from the Bone Marrow Transplant Survivor study, survivors after allogeneic HCT have a risk of premature death that is nearly 10 -fold higher compared to the general population (30). While relapse of the primary disease (29\%), cGVHD (22\%), and late infection in the absence of cGVHD $(11 \%)$ were the three leading causes of death occurring 2 or more years after HCT, subsequent malignancy was the leading cause of late mortality due to treatment related causes and accounted for 7\% of deaths. A similar analysis in survivors after autologous HCT also found a significantly higher risk for premature death (standardized mortality ratio $[\mathrm{SMR}]=13$ compared to the general population). While the majority of deaths were attributed to relapse of the primary disease, $25 \%$ were due to SMNs (12). Recent data from the Seattle group replicated these findings, where recurrent disease (19\%) and subsequent malignancies (26\%) were the two leading causes of death, representing over a 4-fold higher risk of death related to post-HCT solid tumors (28). In this study, SMNs represented a higher percentage of total deaths, likely related to the longer follow-up in the Seattle cohort. While mortality related to SMNs is quantifiable, the morbidity related to a diagnosis of an SMN in HCT survivors has never been adequately ascertained. Many patients have been very heavily treated prior to HCT and have received myeloablative doses of chemotherapy and/or TBI. The tolerability of standard treatment approaches for SMNs is questionable and the additional organ toxicity and other therapy-related side effects can have significant impact on the quality of life of survivors. Little data is available on the success of treatment 
of subsequent cancers; however, in data reported from the University of Minnesota HCT survivors who developed a subsequent solid tumor had a survival at 5 years of $44 \%$ with a median survival time of 1.9 years. For patients with t-MDS/AML after autologous HCT, the median survival was 303 days and survival at 1 year after diagnosis was $34 \%$ (22).

\section{Screening for Subsequent Malignant Neoplasms in Hematopoietic Cell Transplantation Survivors}

There is paucity of data regarding the clinical details at presentation of SMNs, in particular, the clinical stage. Theoretically, if screening practices resulted in subsequent cancers being diagnosed at an earlier stage at time of presentation then treatment would be more successful and survival rates higher. Additionally, less aggressive treatment may be required resulting in less toxicity. The issue of who to screen, how to screen, and when to do it, are all important but largely unanswered questions. For the pediatric survivor population, the Children's Oncology Group has developed comprehensive long-term follow-up guidelines that provide risk-adapted recommendations based on therapeutic exposures and that are supported by the best available published literature (85). For the HCT survivors, screening recommendations must incorporate risks associated with pre-HCT therapy as well from the transplant conditioning therapy and other HCT associated conditions such as cGVHD. Joint recommendations for screening and preventative practices for long-term survivors after HCT from the European Group for Blood and Marrow Transplantation, the Center for International Blood and Marrow Transplant Research, and the American Society of Blood and Marrow Transplant were published in 2006 (86). This reference provides general guidance for SMN screening for HCT survivors but recommendations are limited to annual risk awareness counseling and clinical assessments. General recommendations for colorectal, breast and cervical cancer are provided but are for the most part based on guidelines for the general population. Screening guidelines developed for use in the general population may or may not be sufficient or applicable for use in HCT survivors. For some individuals additional risk factors either pre-HCT (exposure to chest radiation, cranial radiation, alkylating agents, topoisomerase II inhibitors) or associated with HCT (TBI, cGVHD, duration of immunosuppression, T-cell depletion) $(2,4,21,22,32,33,87)$ may lead to elevated risks and must be considered in the screening strategies. Recently published single institution data found that $75 \%$ of HCT survivors were adhering to recommended preventive care guidelines, which is higher than reported for the general population by the National Center for Health Statistics. In addition, rates of adherence to specialized cancer screening testing were high, including $82 \%$ for colonoscopy or sigmoidoscopy, $84 \%$ for Pap smear, and $90 \%$ for mammography (88). Although the median follow-up after HCT was 11 years, $76 \%$ of respondents reported seeing their physician at least once in the past 3 months and thus it may not be too surprising that adherence rates were high in this cohort. Lower adherence rates were associated with autologous HCT, concerns about medical costs, an interval of $>15$ years since HCT, non-white race, male sex, lower physical functioning, and absence of cGVHD.

\section{Risk-Reduction Strategies}

Risk reduction strategies need to utilize a multi-pronged approach, as detailed in Figure 2. Thus, while strategies aimed at altering therapeutic exposures (chemotherapy and radiation) will most likely result in a reduction in the risk of subsequent malignancies in some patients, it is unlikely that these exposures are the only factors that convey risk. In fact, it has been very well documented that recipients of solid organ allografts who subsequently require lifelong immunosuppression, also have a higher risk of developing malignancies presumably secondary to altered immune surveillance (89-91). In HCT recipients, the risk of SMNs is associated with duration of immunosuppression and also to cGVHD (likely from ongoing 
immunosuppression as opposed to an impact of GVHD itself) thus delayed immune recovery or persistent immunodeficiency may contribute to the risk of subsequent malignancy after HCT as well $(2,21)$. Efforts to prevent GVHD and to improve immune reconstitution after HCT may be an effective strategy to reduce the risk of subsequent malignancy.

There is increasing concern related to the risk of cancer and cancer death associated with obesity and a sedentary lifestyle $(92,93)$. Functional and performance limitations and lower levels of physical activity have been reported in HCT survivors, particularly in those who have cGVHD (94-96). Obesity (as determined by body mass index) is uncommon in HCT survivors (97), however, preliminary studies of body composition reveal that they have a high percentage of fat mass and a reduction in muscle mass. This state of sarcopenic obesity contributes to the development insulin resistance, hyperinsulinemia, and chronic inflammation; factors that have been implicated in the causal pathway of obesity-associated cancer risk (98). Thus interventions recommended for the general population aimed at improving nutrition and maintaining a physically active lifestyle are likely of even greater significance for HCT survivors as preventative measures for development of SMNs. Finally, as the pathogenesis of SMNs becomes more clearly elucidated, screening for known genetic susceptibility to cancer could possibly be undertaken and alternative therapeutic options presented to the vulnerable sub-population. These strategies, as well as those encouraged for all, such as avoidance of tobacco and alcohol, use of sunscreen, and HPV vaccination, may help to reduce the risk of SMNs in HCT survivors. Additionally, providing education to our survivors in order to raise awareness of the risk of SMNs and also to the primary care community who will be involved with the long term follow-up and screening of these individuals will be very important.

\section{References}

1. Bhatia S, Ramsay NKC, Steinbuch M, et al. Malignant neoplasms following bone marrow transplantation. Blood. 1996; 87:3633-3639. [PubMed: 8611687]

2. Curtis RE, Rowlings PA, Deeg HJ, et al. Solid cancers after bone marrow transplantation. N Engl J Med. 1997; 336:897-904. [PubMed: 9070469]

3. Krishnan A, Bhatia S, Slovak ML, et al. Predictors of therapy-related leukemia and myelodysplasia following autologous transplantation for lymphoma: an assessment of risk factors. Blood. 2000; 95:1588-1593. [PubMed: 10688812]

4. Rizzo JD, Curtis RE, Socie G, et al. Solid cancers after allogeneic hematopoietic cell transplantation. Blood. 2009; 113:1175-1183. [PubMed: 18971419]

5. Friedman DL, Rovo A, Leisenring W, et al. Increased risk of breast cancer among survivors of allogeneic hematopoietic cell transplantation: a report from the FHCRC and the EBMT-Late Effect Working Party. Blood. 2008; 111:939-944. [PubMed: 17911386]

6. Cohen A, Rovelli A, Merlo DF, et al. Risk for secondary thyroid carcinoma after hematopoietic stem-cell transplantation: an EBMT Late Effects Working Party Study. J Clin Oncol. 2007; 25:2449-2454. [PubMed: 17557958]

7. Witherspoon RP, Fisher LD, Schoch G, et al. Secondary cancers after bone marrow transplantation for leukemia or aplastic anemia. N Engl J Med. 1989; 321:784-789. [PubMed: 2671734]

8. Gilliland DG, Gribben JG. Evaluation of the risk of therapy-related MDS/AML after autologous stem cell transplantation. Biol Blood Marrow Transplant. 2002; 8:9-16. [PubMed: 11846355]

9. Milligan DW, Ruiz De Elvira MC, Kolb HJ, et al. Secondary leukaemia and myelodysplasia after autografting for lymphoma: results from the EBMT. EBMT Lymphoma and Late Effects Working Parties. European Group for Blood and Marrow Transplantation. Br J Haematol. 1999; 106:1020 1026. [PubMed: 10520006]

10. Stone RM. Myelodysplastic syndrome after autologous transplantation for lymphoma: the price of progress. Blood. 1994; 83:3437-3440. [PubMed: 8204870] 
11. Friedberg JW, Neuberg D, Stone RM, et al. Outcome in patients with myelodysplastic syndrome after autologous bone marrow transplantation for non-Hodgkin's lymphoma. J Clin Oncol. 1999; 17:3128-3135. [PubMed: 10506609]

12. Bhatia S, Robison LL, Francisco L, et al. Late mortality in survivors of autologous hematopoieticcell transplantation: report from the Bone Marrow Transplant Survivor Study. Blood. 2005; 105:4215-4222. [PubMed: 15701723]

13. Witherspoon RP, Deeg HJ. Allogeneic bone marrow transplantation for secondary leukemia or myelodysplasia. Haematologica. 1999; 84:1085-1087. [PubMed: 10586209]

14. Bloomfield CD, Archer KJ, Mrozek K, et al. 11q23 balanced chromosome aberrations in treatment-related myelodysplastic syndromes and acute leukemia: report from an international workshop. Genes Chromosomes Cancer. 2002; 33:362-378. [PubMed: 11921271]

15. Litzow MR, Tarima S, Perez WS, et al. Allogeneic transplantation for therapy-related myelodysplastic syndrome and acute myeloid leukemia. Blood. 2009; 115:1850-1857. [PubMed: 20032503]

16. Landgren O, Gilbert ES, Rizzo JD, et al. Risk factors for lymphoproliferative disorders after allogeneic hematopoietic cell transplantation. Blood. 2009; 113:4992-5001. [PubMed: 19264919]

17. Curtis RE, Travis LB, Rowlings PA, et al. Risk of lymphoproliferative disorders after bone marrow transplantation: a multi-institutional study. Blood. 1999; 94:2208-2216. [PubMed: 10498590]

18. Schouten HC, Hopman AH, Haesevoets AM, Arends JW. Large-cell anaplastic non-Hodgkin's lymphoma originating in donor cells after allogenic bone marrow transplantation. Br J Haematol. 1995; 91:162-166. [PubMed: 7577625]

19. Rowlings PA, Curtis RE, Passweg JR, et al. Increased incidence of Hodgkin's disease after allogeneic bone marrow transplantation. J Clin Oncol. 1999; 17:3122-3127. [PubMed: 10506608]

20. Bhatia S, Louie AD, Bhatia R, et al. Solid cancers after bone marrow transplantation. Journal of Clinical Oncology. 2001; 19:464-471. [PubMed: 11208840]

21. Kolb HJ, Socie G, Duell T, et al. Malignant neoplasms in long-term survivors of bone marrow transplantation. Late Effects Working Party of the European Cooperative Group for Blood and Marrow Transplantation and the European Late Effect Project Group. Ann Intern Med. 1999; 131:738-744. [PubMed: 10577296]

22. Baker KS, DeFor TE, Burns LJ, Ramsay NK, Neglia JP, Robison LL. New malignancies after blood or marrow stem-cell transplantation in children and adults: incidence and risk factors. J Clin Oncol. 2003; 21:1352-1358. [PubMed: 12663726]

23. Shimada K, Yokozawa T, Atsuta Y, et al. Solid tumors after hematopoietic stem cell transplantation in Japan: incidence, risk factors and prognosis. Bone Marrow Transplant. 2005; 36:115-121. [PubMed: 15908969]

24. Gallagher G, Forrest DL. Second solid cancers after allogeneic hematopoietic stem cell transplantation. Cancer. 2007:84-92. [PubMed: 17131350]

25. Leisenring W, Friedman DL, Flowers ME, Schwartz JL, Deeg HJ. Nonmelanoma skin and mucosal cancers after hematopoietic cell transplantation. J Clin Oncol. 2006; 24:1119-1126. [PubMed: 16461782]

26. Socie G, Stone JV, Wingard JR, et al. Long-term survival and late deaths after allogeneic bone marrow transplantation. Late Effects Working Committee of the International Bone Marrow Transplant Registry. N Engl J Med. 1999; 341:14-21. [PubMed: 10387937]

27. Wingard JR, Majhail NS, Brazauskas R, et al. Long-term survival and late deaths after allogeneic hematopoietic cell transplantation. J Clin Oncol. 2011; 29:2230-2239. [PubMed: 21464398]

28. Martin PJ, Counts GW Jr, Appelbaum FR, et al. Life expectancy in patients surviving more than 5 years after hematopoietic cell transplantation. J Clin Oncol. 2010; 28:1011-1016. [PubMed: 20065176]

29. Duell T, van Lint MT, Ljungman P, et al. Health and functional status of long-term survivors of bone marrow transplantation. EBMT Working Party on Late Effects and EULEP Study Group on Late Effects. European Group for Blood and Marrow Transplantation. Ann Intern Med. 1997; 126:184-192. [PubMed: 9027268] 
30. Bhatia S, Francisco L, Carter A, et al. Late mortality after allogeneic hematopoietic cell transplantation and functional status of long-term survivors: report from the Bone Marrow Transplant Survivor Study. Blood. 2007; 110:3784-3792. [PubMed: 17671231]

31. Socie G, Henry-Amar M, Cosset JM, Devergie A, Girinsky T, Gluckman E. Increased incidence of solid malignant tumors after bone marrow transplantation for severe aplastic anemia. Blood. 1991; 78:277-279. [PubMed: 2070065]

32. Deeg HJ, Socie G, Schoch G, et al. Malignancies after marrow transplantation for aplastic anemia and fanconi anemia: a joint Seattle and Paris analysis of results in 700 patients. Blood. 1996; 87:386-392. [PubMed: 8547667]

33. Socie G, Curtis RE, Deeg HJ, et al. New malignant diseases after allogeneic marrow transplantation for childhood acute leukemia. J Clin Oncol. 2000; 18:348-357. [PubMed: 10637249]

34. Curtis RE, Metayer C, Rizzo JD, et al. Impact of chronic GVHD therapy on the development of squamous-cell cancers after hematopoietic stem-cell transplantation: an international case-control study. Blood. 2005; 105:3802-3811. [PubMed: 15687239]

35. Majhail NS, Brazauskas R, Rizzo JD, et al. Secondary solid cancers after allogeneic hematopoietic cell transplantation using busulfan-cyclophosphamide conditioning. Blood. 2011; 117:316-322. [PubMed: 20926773]

36. Schwartz JL, Kopecky KJ, Mathes RW, Leisenring WM, Friedman DL, Deeg HJ. Basal cell skin cancer after total-body irradiation and hematopoietic cell transplantation. Radiat Res. 2009; 171:155-163. [PubMed: 19267540]

37. Kenney LB, Yasui Y, Inskip PD, et al. Breast cancer after childhood cancer: a report from the Childhood Cancer Survivor Study. Ann Intern Med. 2004; 141:590-597. [PubMed: 15492338]

38. Travis LB, Hill D, Dores GM, et al. Cumulative absolute breast cancer risk for young women treated for Hodgkin lymphoma. J Natl Cancer Inst. 2005; 97:1428-1437. [PubMed: 16204692]

39. Henderson TO, Whitton J, Stovall M, et al. Secondary sarcomas in childhood cancer survivors: a report from the Childhood Cancer Survivor Study. J Natl Cancer Inst. 2007; 99:300-308. [PubMed: 17312307]

40. van Leeuwen, FE.; Travis, LB. Second Cancers. In: DeVita, HS.; Rosenberg, SA., editors. Cancer: principles and practice of oncology 7th edition. Philadelphia: Lippincott Williams and Wilkins; 2005. p. 2575-2602.

41. Limacher JM, Frebourg T, Natarajan-Ame S, Bergerat JP. Two metachronous tumors in the radiotherapy fields of a patient with Li-Fraumeni syndrome. Int J Cancer. 2001; 96:238-242. [PubMed: 11474498]

42. Alter BP. Cancer in Fanconi anemia, 1927-2001. Cancer. 2003; 97:425-440. [PubMed: 12518367]

43. Rosenberg PS, Alter BP, Ebell W. Cancer risks in Fanconi anemia: findings from the German Fanconi Anemia Registry. Haematologica. 2008; 93:511-517. [PubMed: 18322251]

44. Kalow W, Ozdemir V, Tang BK, Tothfalusi L, Endrenyi L. The science of pharmacological variability: an essay. Clin Pharmacol Ther. 1999; 66:445-447. [PubMed: 10579470]

45. Evans WE, McLeod HL. Pharmacogenomics--drug disposition, drug targets, and side effects. N Engl J Med. 2003; 348:538-549. [PubMed: 12571262]

46. Berwick M, Vineis P. Markers of DNA repair and susceptibility to cancer in humans: an epidemiologic review. J Natl Cancer Inst. 2000; 92:874-897. [PubMed: 10841823]

47. Goode EL, Ulrich CM, Potter JD. Polymorphisms in DNA repair genes and associations with cancer risk. Cancer Epidemiol Biomarkers Prev. 2002; 11:1513-1530. [PubMed: 12496039]

48. Bhatti P, Doody MM, Alexander BH, et al. Breast cancer risk polymorphisms and interaction with ionizing radiation among U.S. radiologic technologists. Cancer Epidemiol Biomarkers Prev. 2008; 17:2007-2011. [PubMed: 18708391]

49. Bhatti P, Struewing JP, Alexander BH, et al. Polymorphisms in DNA repair genes, ionizing radiation exposure and risk of breast cancer in U.S. Radiologic technologists. Int J Cancer. 2008; 122:177-182. [PubMed: 17764108]

50. Rajaraman P, Bhatti P, Doody MM, et al. Nucleotide excision repair polymorphisms may modify ionizing radiation-related breast cancer risk in US radiologic technologists. Int J Cancer. 2008; 123:2713-2716. [PubMed: 18767034] 
51. Worrillow LJ, Travis LB, Smith AG, et al. An intron splice acceptor polymorphism in hMSH2 and risk of leukemia after treatment with chemotherapeutic alkylating agents. Clin Cancer Res. 2003; 9:3012-3020. [PubMed: 12912950]

52. Allan JM, Smith AG, Wheatley K, et al. Genetic variation in XPD predicts treatment outcome and risk of acute myeloid leukemia following chemotherapy. Blood. 2004; 104:3872-3877. [PubMed: 15339847]

53. Mertens AC, Mitby PA, Radloff G, et al. XRCC1 and glutathione-S-transferase gene polymorphisms and susceptibility to radiotherapy-related malignancies in survivors of Hodgkin disease. Cancer. 2004; 101:1463-1472. [PubMed: 15368334]

54. Worrillow LJ, Smith AG, Scott K, et al. Polymorphic MLH1 and risk of cancer after methylating chemotherapy for Hodgkin lymphoma. J Med Genet. 2008; 45:142-146. [PubMed: 17959715]

55. McFadyen MC, Melvin WT, Murray GI. Cytochrome P450 enzymes: novel options for cancer therapeutics. Mol Cancer Ther. 2004; 3:363-371. [PubMed: 15026557]

56. Park JY, Shigenaga MK, Ames BN. Induction of cytochrome P4501A1 by 2,3,7,8tetrachlorodibenzo-p-dioxin or indolo(3,2-b)carbazole is associated with oxidative DNA damage. Proc Natl Acad Sci U S A. 1996; 93:2322-2327. [PubMed: 8637871]

57. Hayes JD, Flanagan JU, Jowsey IR. Glutathione transferases. Annu Rev Pharmacol Toxicol. 2005; 45:51-88. [PubMed: 15822171]

58. Allan JM, Wild CP, Rollinson S, et al. Polymorphism in glutathione S-transferase P1 is associated with susceptibility to chemotherapy-induced leukemia. Proc Natl Acad Sci U S A. 2001; 98:11592-11597. [PubMed: 11553769]

59. Collins A, Harrington V. Repair of oxidative DNA damage: assessing its contribution to cancer prevention. Mutagenesis. 2002; 17:489-493. [PubMed: 12435846]

60. Karran P, Offman J, Bignami M. Human mismatch repair, drug-induced DNA damage, and secondary cancer. Biochimie. 2003; 85:1149-1160. [PubMed: 14726020]

61. Casorelli I, Offman J, Mele L, et al. Drug treatment in the development of mismatch repair defective acute leukemia and myelodysplastic syndrome. DNA Repair (Amst). 2003; 2:547-559. [PubMed: 12713812]

62. Seedhouse CH, Das-Gupta EP, Russell NH. Methylation of the hMLH1 promoter and its association with microsatellite instability in acute myeloid leukemia. Leukemia. 2003; 17:83-88. [PubMed: 12529664]

63. Zhu YM, Das-Gupta EP, Russell NH. Microsatellite instability and p53 mutations are associated with abnormal expression of the MSH2 gene in adult acute leukemia. Blood. 1999; 94:733-740. [PubMed: 10397740]

64. Horiike S, Misawa S, Kaneko H, et al. Distinct genetic involvement of the TP53 gene in therapyrelated leukemia and myelodysplasia with chromosomal losses of Nos 5 and/or 7 and its possible relationship to replication error phenotype. Leukemia. 1999; 13:1235-1242. [PubMed: 10450752]

65. Fishel R, Lescoe MK, Rao MR, et al. The human mutator gene homolog MSH2 and its association with hereditary nonpolyposis colon cancer. Cell. 1993; 75:1027-1038. [PubMed: 8252616]

66. Brentnall TA, Rubin CE, Crispin DA, et al. A germline substitution in the human MSH2 gene is associated with high-grade dysplasia and cancer in ulcerative colitis. Gastroenterology. 1995; 109:151-155. [PubMed: 7797014]

67. Worrillow LJ, Allan JM. Deregulation of homologous recombination DNA repair in alkylating agent-treated stem cell clones: a possible role in the aetiology of chemotherapy-induced leukaemia. Oncogene. 2006; 25:1709-1720. [PubMed: 16278672]

68. O'Driscoll M, Jeggo PA. The role of double-strand break repair - insights from human genetics. Nat Rev Genet. 2006; 7:45-54. [PubMed: 16369571]

69. Baumann P, West SC. Role of the human RAD51 protein in homologous recombination and double-stranded-break repair. Trends Biochem Sci. 1998; 23:247-251. [PubMed: 9697414]

70. Jawad M, Seedhouse CH, Russell N, Plumb M. Polymorphisms in human homeobox HLX1 and DNA repair RAD51 genes increase the risk of therapy-related acute myeloid leukemia. Blood. 2006; 108:3916-3918. [PubMed: 16902145] 
71. Seedhouse C, Faulkner R, Ashraf N, Das-Gupta E, Russell N. Polymorphisms in genes involved in homologous recombination repair interact to increase the risk of developing acute myeloid leukemia. Clin Cancer Res. 2004; 10:2675-2680. [PubMed: 15102670]

72. Bishop DK, Ear U, Bhattacharyya A, et al. Xrcc3 is required for assembly of Rad51 complexes in vivo. J Biol Chem. 1998; 273:21482-21488. [PubMed: 9705276]

73. Liu N, Lamerdin JE, Tebbs RS, et al. XRCC2 and XRCC3, new human Rad51-family members, promote chromosome stability and protect against DNA cross-links and other damages. Mol Cell. 1998; 1:783-793. [PubMed: 9660962]

74. Tebbs RS, Zhao Y, Tucker JD, et al. Correction of chromosomal instability and sensitivity to diverse mutagens by a cloned cDNA of the XRCC3 DNA repair gene. Proc Natl Acad Sci U S A. 1995; 92:6354-6358. [PubMed: 7603995]

75. Pierce AJ, Johnson RD, Thompson LH, Jasin M. XRCC3 promotes homology-directed repair of DNA damage in mammalian cells. Genes Dev. 1999; 13:2633-2638. [PubMed: 10541549]

76. Matullo G, Palli D, Peluso M, et al. XRCC1, XRCC3, XPD gene polymorphisms, smoking and (32) P-DNA adducts in a sample of healthy subjects. Carcinogenesis. 2001; 22:1437-1445. [PubMed: 11532866]

77. Au WW, Salama SA, Sierra-Torres CH. Functional characterization of polymorphisms in DNA repair genes using cytogenetic challenge assays. Environ Health Perspect. 2003; 111:1843-1850. [PubMed: 14630517]

78. Caldecott KW, McKeown CK, Tucker JD, Ljungquist S, Thompson LH. An interaction between the mammalian DNA repair protein XRCC1 and DNA ligase III. Mol Cell Biol. 1994; 14:68-76. [PubMed: 8264637]

79. Kubota Y, Nash RA, Klungland A, Schar P, Barnes DE, Lindahl T. Reconstitution of DNA base excision-repair with purified human proteins: interaction between DNA polymerase beta and the XRCC1 protein. EMBO J. 1996; 15:6662-6670. [PubMed: 8978692]

80. Seedhouse C, Bainton R, Lewis M, Harding A, Russell N, Das-Gupta E. The genotype distribution of the XRCC1 gene indicates a role for base excision repair in the development of therapy-related acute myeloblastic leukemia. Blood. 2002; 100:3761-3766. [PubMed: 12393447]

81. Nelson HH, Kelsey KT, Mott LA, Karagas MR. The XRCC1 Arg399Gln polymorphism, sunburn, and non-melanoma skin cancer: evidence of gene-environment interaction. Cancer Res. 2002; 62:152-155. [PubMed: 11782372]

82. Ellis NA, Huo D, Yildiz O, et al. MDM2 SNP309 and TP53 Arg72Pro interact to alter therapyrelated acute myeloid leukemia susceptibility. Blood. 2008; 112:741-749. [PubMed: 18426989]

83. Knight JA, Skol AD, Shinde A, et al. Genome-wide association study to identify novel loci associated with therapy-related myeloid leukemia susceptibility. Blood. 2009; 113:5575-5582. [PubMed: 19299336]

84. Best T, Li D, Skol AD, et al. Variants at 6q21 implicate PRDM1 in the etiology of therapy-induced second malignancies after Hodgkin's lymphoma. Nat Med. 2011; 17:941-943. [PubMed: 21785431]

85. Children's Oncology Group. Long-Term Follow-up Guidelines for Survivors of Childhood A, and Young Adult Cancers. Version 3.0.

86. Rizzo JD, Wingard JR, Tichelli A, et al. Recommended screening and preventive practices for long-term survivors after hematopoietic cell transplantation: joint recommendations of the European Group for Blood and Marrow Transplantation, the Center for International Blood and Marrow Transplant Research, and the American Society of Blood and Marrow Transplantation. Biol Blood Marrow Transplant. 2006; 12:138-151. [PubMed: 16443512]

87. Bhatia S, Meadows AT, Robison LL. Second cancers after pediatric Hodgkin's disease. J Clin Oncol. 1998; 16:2570-2572. [PubMed: 9667281]

88. Khera N, Chow EJ, Leisenring WM, et al. Factors associated with adherence to preventive care practices among hematopoietic cell transplantation survivors. Biol Blood Marrow Transplant. 2011; 17:995-1003. [PubMed: 21145404]

89. Stockfleth E, Ulrich C, Meyer T, Christophers E. Epithelial malignancies in organ transplant patients: clinical presentation and new methods of treatment. Recent Results Cancer Res. 2002; 160:251-258. [PubMed: 12079221] 
90. Romero-Vargas ME, Flores-Cortes M, Valera Z, et al. Cancers of new appearance in liver transplant recipients: incidence and evolution. Transplant Proc. 2006; 38:2508-2510. [PubMed: 17097983]

91. Abu-Elmagd KM, Mazariegos G, Costa G, et al. Lymphoproliferative disorders and de novo malignancies in intestinal and multivisceral recipients: improved outcomes with new outlooks. Transplantation. 2009; 88:926-934. [PubMed: 19935465]

92. Byers T, Nestle M, McTiernan A, et al. American Cancer Society guidelines on nutrition and physical activity for cancer prevention: Reducing the risk of cancer with healthy food choices and physical activity. CA Cancer J Clin. 2002; 52:92-119. [PubMed: 11929008]

93. Calle EE, Rodriguez C, Walker-Thurmond K, Thun MJ. Overweight, obesity, and mortality from cancer in a prospectively studied cohort of U.S. adults. N Engl J Med. 2003; 348:1625-1638. [PubMed: 12711737]

94. Ness KK, Bhatia S, Baker KS, et al. Performance limitations and participation restrictions among childhood cancer survivors treated with hematopoietic stem cell transplantation: the bone marrow transplant survivor study. Arch Pediatr Adolesc Med. 2005; 159:706-713. [PubMed: 16061776]

95. Baker KS, Gurney JG, Ness KK, et al. Late effects in survivors of chronic myeloid leukemia treated with hematopoietic cell transplantation: results from the Bone Marrow Transplant Survivor Study. Blood. 2004; 104:1898-1906. [PubMed: 15172972]

96. Fraser CJ, Bhatia S, Ness K, et al. Impact of chronic graft-versus-host disease on the health status of hematopoietic cell transplantation survivors: a report from the Bone Marrow Transplant Survivor Study. Blood. 2006; 108:2867-2873. [PubMed: 16788100]

97. Baker KS, Ness KK, Steinberger J, et al. Diabetes, hypertension, and cardiovascular events in survivors of hematopoietic cell transplantation: a report from the bone marrow transplantation survivor study. Blood. 2007; 109:1765-1772. [PubMed: 17047152]

98. Baker KS, Chow EJ, Goodman P, et al. Adverse Impact of Hematopoietic Cell Transplantation (HCT) on Body Composition and Insulin Resistance is Associated with Increased Cardiovascular Risk. Biol Blood Marrow Transplant. 2011; 17 Supplement 1(Issue 2):S174-S175. 


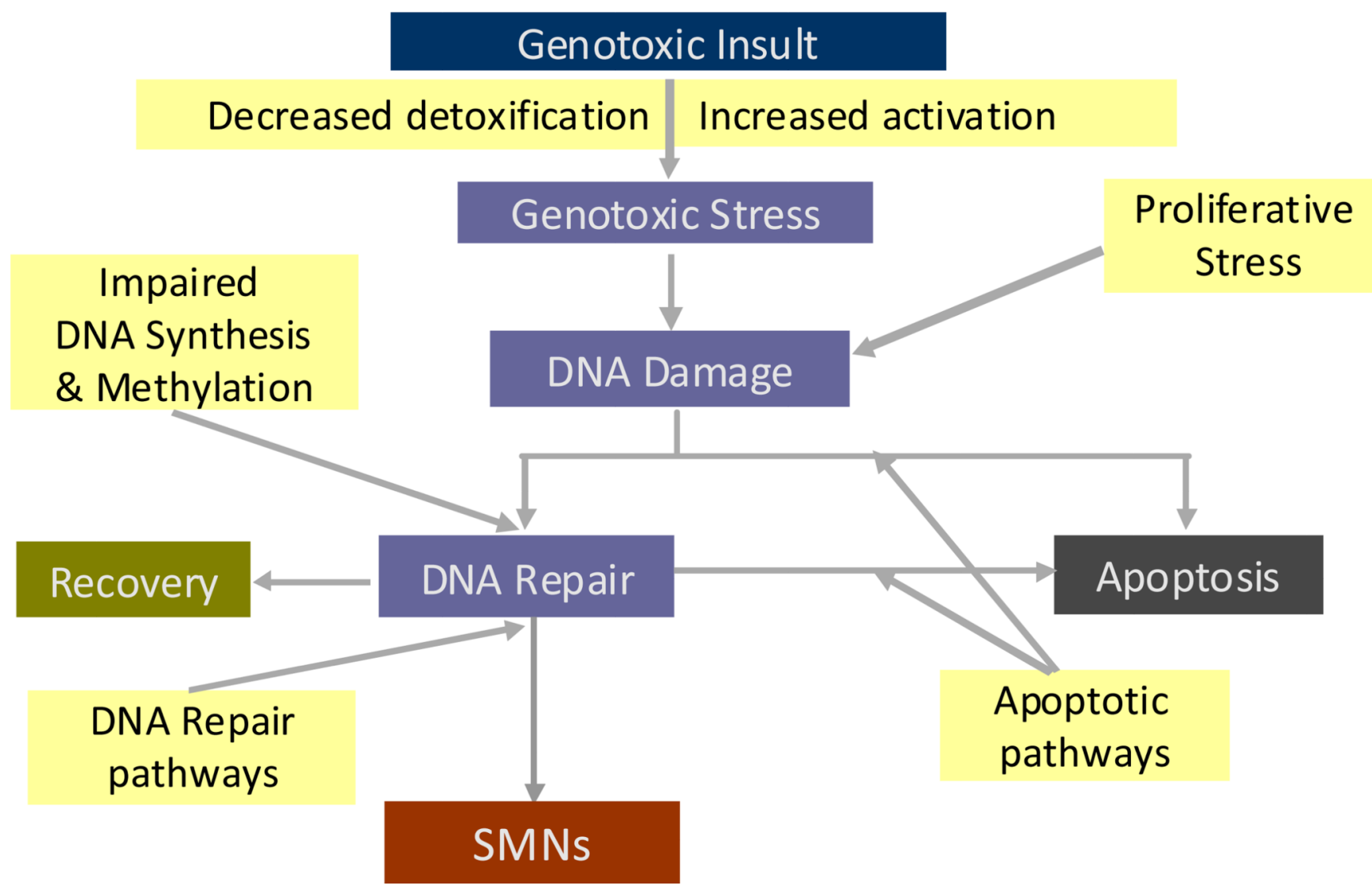

Figure 1.

Therapy-related SMN - Hypothesized Mechanisms for Genetic Susceptibility 


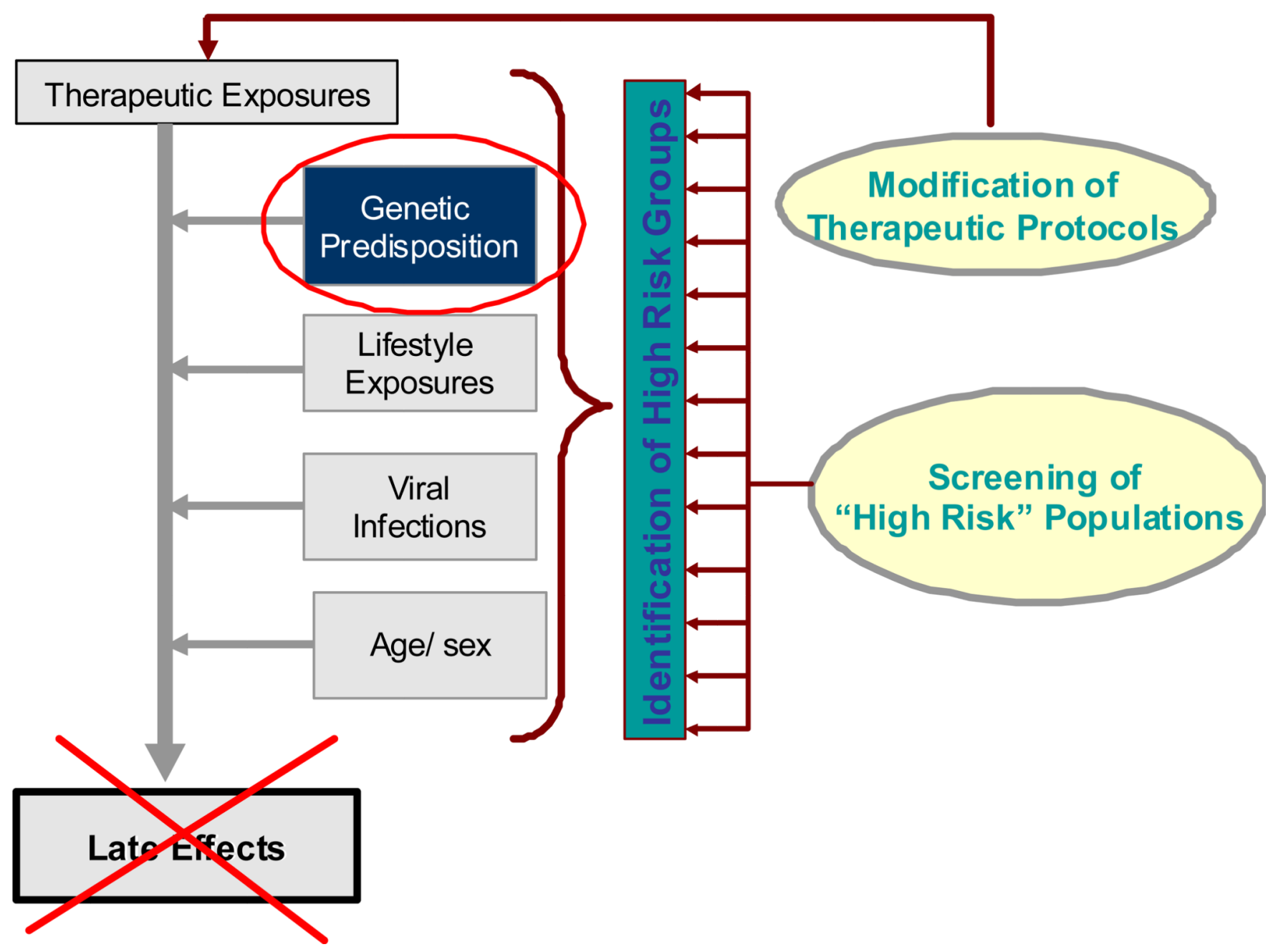

Figure 2.

Long-term Risk-Reduction Strategies 
Table 1

Magnitude of Risk and Populations at Increased Risk of Subsequent Malignant Neoplasms after Hematopoietic cell Transplantation

\begin{tabular}{|c|c|c|c|c|}
\hline Study & Study design & $\begin{array}{l}\text { Sample size/ number of } \\
\text { SMNs }\end{array}$ & $\begin{array}{l}\text { Primary Diagnoses; Type } \\
\text { of HCT }\end{array}$ & $\begin{array}{l}\text { Magnitude of Risk } \\
\text { and Risk Factors }\end{array}$ \\
\hline \multicolumn{5}{|c|}{ All second malignant neoplasms } \\
\hline $\begin{array}{l}\text { Witherspoon RP et } \\
\text { al. N Engl J Med. } \\
\text { 1989;321:784-789 } \\
\text { (7) }\end{array}$ & Retrospective cohort study & $\begin{array}{l}\text { 2,246/35 leukemia, } \\
\text { lymphoma, solid } \\
\text { malignancies }\end{array}$ & $\begin{array}{l}\text { Autologous or allogeneic } \\
\text { HCT }\end{array}$ & $\begin{array}{l}\text { 6.7-fold increased risk } \\
\text { compared with } \\
\text { general population } \\
\text { Acute GvHD treated } \\
\text { with ATG or antiCD3 } \\
\text { antibody, TBI were } \\
\text { associated with } \\
\text { increased risk of SMN }\end{array}$ \\
\hline $\begin{array}{l}\text { Bhatia S, et al. } \\
\text { Blood. } \\
\text { 1996;87:3633- } \\
3639 \text { (1) }\end{array}$ & Retrospectic cohort study & $\begin{array}{l}\text { 2150/ } 53 \text { leukemia, } \\
\text { lymphoma, solid } \\
\text { malignancies }\end{array}$ & $\begin{array}{l}\text { All hematologic } \\
\text { malignancies, inborn } \\
\text { diseases of immune system } \\
\text { Autologous and allogeneic } \\
\text { HCT }\end{array}$ & $\begin{array}{l}\text { 11.6-fold increased } \\
\text { risk compared with } \\
\text { general population } \\
\text { Cumulative } \\
\text { probability: } 9.9 \% \text { at } \\
13 \text { years for all SMNs; } \\
1.6 \% \text { at } 4 \text { years for } \\
\text { PTLD; } 5.6 \% \text { at } 13 \\
\text { years for solid } \\
\text { malignancies. T-cell } \\
\text { depletion, use of } \\
\text { ATG, unrelated donor } \\
\text { HCT, primary } \\
\text { immune deficiency } \\
\text { associated with } \\
\text { increased risk of } \\
\text { PTLD; }\end{array}$ \\
\hline $\begin{array}{l}\text { Deeg HJ et al. } \\
\text { Blood 1996; } \\
\text { 87:386-92 (32) }\end{array}$ & Retrospective cohort & $\begin{array}{l}\text { 700/23 leukemias (ALL), } \\
\text { solid tumors and lymphomas }\end{array}$ & $\begin{array}{l}\text { Severe aplastic anemia } \\
\text { Allogeneic HCT }\end{array}$ & $\begin{array}{l}\text { Cumulative } \\
\text { probability: } 14 \% \text { at } 20 \\
\text { years } \\
\text { Azathioprine; } \\
\text { diagnosis of Fanconi } \\
\text { anemia; irradiation } \\
\text { and age at HCT in the } \\
\text { non-Fanconi cohort }\end{array}$ \\
\hline $\begin{array}{l}\text { Kolb HJ et al. Ann } \\
\text { Intern Med 1999; } \\
\text { 131:738-44 (21) }\end{array}$ & Retrospective cohort study & $\begin{array}{l}\text { 1036/ } 53 \text { leukemia, } \\
\text { lymphoma, solid } \\
\text { malignancies }\end{array}$ & $\begin{array}{l}\text { Leukemia, lymphoma, } \\
\text { inborn diseases of } \\
\text { hematopoietic and immune } \\
\text { systems, severe aplastic } \\
\text { anemia } \\
\text { Autologous and allogeneic }\end{array}$ & $\begin{array}{l}\text { Cumulative } \\
\text { probability: } 3.5 \% \text { at } \\
10 \text { years; } \\
3.8 \text {-fold increased risk } \\
\text { compared with } \\
\text { general population; } \\
\text { Older age at HCT and } \\
\text { treatment of chronic } \\
\text { GvHD with } \\
\text { cyclosporine } \\
\text { associated with } \\
\text { increased risk }\end{array}$ \\
\hline $\begin{array}{l}\text { Baker KS et al. J } \\
\text { Clin Oncol 2003; } \\
\text { 21:1352-8 (22) }\end{array}$ & Retrospective cohort study & $\begin{array}{l}\text { 3,372/ } 147 \text { leukemia, } \\
\text { lymphoma and solid } \\
\text { malignancies }\end{array}$ & $\begin{array}{l}\text { All malignancies and } \\
\text { metabolic disorders; } \\
\text { immune deficiency; aplastic } \\
\text { anemia } \\
\text { Autologous and allogeneic }\end{array}$ & $\begin{array}{l}\text { 8.1-fold increased risk } \\
\text { compared with } \\
\text { general population; } \\
\text { Cumulative incidence: } \\
6.9 \% \text { at } 20 \text { years for } \\
\text { any malignancy; } 1.4 \% \\
\text { at } 10 \text { years for PTLD; } \\
1.4 \% \text { at } 10 \text { years for } \\
\text { MDS/AML; } 3.8 \% \text { at } \\
20 \text { years for solid } \\
\text { tumors }\end{array}$ \\
\hline \multicolumn{5}{|c|}{ Post-Transplantation Lymphoproliferative Disorders } \\
\hline $\begin{array}{l}\text { Landgren } \mathrm{O} \text { et al. } \\
\text { Blood. }\end{array}$ & Retrospective cohort study & 26,901/ 127 PTLD & $\begin{array}{l}\text { Hematologic malignancies } \\
\text { and severe aplastic anemia }\end{array}$ & $\begin{array}{l}\text { T-cell depletion, use } \\
\text { of ATG, unrelated }\end{array}$ \\
\hline
\end{tabular}




\begin{tabular}{|c|c|c|c|c|}
\hline Study & Study design & $\begin{array}{l}\text { Sample size/ number of } \\
\text { SMNs }\end{array}$ & $\begin{array}{l}\text { Primary Diagnoses; Type } \\
\text { of HCT }\end{array}$ & $\begin{array}{l}\text { Magnitude of Risk } \\
\text { and Risk Factors }\end{array}$ \\
\hline $\begin{array}{l}2009 ; 113: 4992- \\
5001(16)\end{array}$ & & & Allogeneic HCT & $\begin{array}{l}\text { donor HLA- } \\
\text { mismatched grafts. } \\
\text { Cumulative risk } \\
\text { increased to } 8.1 \% \\
\text { with more than } 3 \text { risk } \\
\text { factors }\end{array}$ \\
\hline $\begin{array}{l}\text { Curtis RE et al. } \\
\text { Blood. } \\
\text { 1999;94:2208- } \\
2216(17)\end{array}$ & Retrospective cohort study & 18,014/78 PTLD & $\begin{array}{l}\text { Hematologic malignancies } \\
\text { Allogeneic HCT }\end{array}$ & $\begin{array}{l}\text { Cumulative incidence } \\
1 \% \text { at } 10 \text { years } \\
\text { Unrelated donor HCT, } \\
\text { T-cell depletion, use } \\
\text { of ATG, use of anti- } \\
\text { CD3 monoclonal } \\
\text { antibody }\end{array}$ \\
\hline \multicolumn{5}{|c|}{ Therapy-related myelodysplasia/ acute myeloid leukemia } \\
\hline $\begin{array}{l}\text { Krishnan A et al. } \\
\text { Blood. } \\
2000 ; 95: 1588- \\
1593(3)\end{array}$ & $\begin{array}{l}\text { Retrospective cohort study } \\
\text { Nested case-control study }\end{array}$ & $612 / 22 \mathrm{MDS} / \mathrm{AML}$ & $\begin{array}{l}\text { Hodgkin lymphoma } \\
\text { Non-Hodgkin lymphoma } \\
\text { Autologous HCT }\end{array}$ & $\begin{array}{l}\text { Cumulative } \\
\text { probability of MDS/ } \\
\text { AM L }: 8.6 \% \text { at } 6 \\
\text { years } \\
\text { Stem cell priming } \\
\text { with VP-16, pre-HCT } \\
\text { radiation associated } \\
\text { with increased risk of } \\
\text { t-MDS/AML }\end{array}$ \\
\hline $\begin{array}{l}\text { Milligan DW et al. } \\
\text { Br J Haematol. } \\
\text { 1999;106:1020- } \\
1026 \text { (9) }\end{array}$ & Retrospective cohort design & 4,998/ $66 \mathrm{MDS} / \mathrm{AML}$ & $\begin{array}{l}\text { Hodgkin lymphoma } \\
\text { Non-Hodgkin lymphoma } \\
\text { Autologous HCT }\end{array}$ & $\begin{array}{l}\text { 5-year cumulative } \\
\text { probability was } 4.6 \% \\
\text { for HL and } 3 \% \text { for } \\
\text { NHL. } \\
\text { Older age at HCT, } \\
\text { diagnosis of HL, } \\
\text { exposure to TBI, } \\
\text { multiple HCT, years } \\
\text { between diagnosis } \\
\text { were associated with } \\
\text { increased risk of } \\
\text { MDS/AML }\end{array}$ \\
\hline \multicolumn{5}{|l|}{ Solid Malignancies } \\
\hline $\begin{array}{l}\text { Curtis RE et al. N } \\
\text { Engl J Med. } \\
\text { 1997;336:897-904 } \\
\text { (2) }\end{array}$ & Retrospective cohort & $\begin{array}{l}19,229 / 80 \text { solid } \\
\text { malignancies }\end{array}$ & Allogeneic HCT & $\begin{array}{l}\text { 2.7-fold increased risk } \\
\text { of solid malignancies } \\
\text { compared with teh } \\
\text { general population } \\
\text { Cumulative incidence; } \\
6.7 \% \text { at } 15 \text { years; } \\
\text { younger age at HCT } \\
\text { associated with } \\
\text { increased risk of solid } \\
\text { malignancies; chronic } \\
\text { GvHD and male sex } \\
\text { associated with } \\
\text { increased risk of } \\
\text { squamous cell } \\
\text { carcinoma }\end{array}$ \\
\hline $\begin{array}{l}\text { Bhatia S, et al. J } \\
\text { Clin Oncol 2001; } \\
\text { 19:464-71 (20) }\end{array}$ & Retrospective cohort study & $2,129 / 29$ solid malignancies & $\begin{array}{l}\text { Hematologic malignancies } \\
\text { Autologous and allogeneic } \\
\text { HCT }\end{array}$ & $\begin{array}{l}\text { 2-fold increased risk } \\
\text { compared with } \\
\text { general population } \\
\text { Cumulative } \\
\text { probability: } 6.1 \% \text { at } \\
10 \text { years }\end{array}$ \\
\hline $\begin{array}{l}\text { Rizzo JD et al. } \\
\text { Blood. } \\
2009 ; 113: 1175- \\
1183 \text { (4) }\end{array}$ & Retrospective cohort study & $\begin{array}{l}28,874 / 189 \text { solid } \\
\text { malignancies }\end{array}$ & $\begin{array}{l}\text { Hematologic malignancies } \\
\text { and hemoglobinopathies } \\
\text { Allogeneic HCT recipients }\end{array}$ & $\begin{array}{l}\text { 2-fold increased risk } \\
\text { compared with } \\
\text { general population } \\
\text { Chronic GvHD and } \\
\text { male sex were } \\
\text { associated with } \\
\text { squamous cell } \\
\text { carcinoma }\end{array}$ \\
\hline
\end{tabular}




\begin{tabular}{|c|c|c|c|c|}
\hline Study & Study design & $\begin{array}{l}\text { Sample size/ number of } \\
\text { SMNs }\end{array}$ & $\begin{array}{l}\text { Primary Diagnoses; Type } \\
\text { of HCT }\end{array}$ & $\begin{array}{l}\text { Magnitude of Risk } \\
\text { and Risk Factors }\end{array}$ \\
\hline $\begin{array}{l}\text { Shimada K et al. } \\
\text { Bone Marrow } \\
\text { Transplant 2005; } \\
\text { 36:115-21 (23) }\end{array}$ & Retrospective cohort study & $809 / 19$ solid malignancies & $\begin{array}{l}\text { All malignancies } \\
\text { Autologous and allogeneic } \\
\text { HCT }\end{array}$ & $\begin{array}{l}\text { 2.8-fold increased risk } \\
\text { Cumulative incidence: } \\
4.2 \% \text { at } 10 \text { years; } \\
\text { Extensive chronic } \\
\text { GvHD and older age } \\
\text { were associated with } \\
\text { increased risk }\end{array}$ \\
\hline $\begin{array}{l}\text { Gallagher G et al. } \\
\text { Cancer 2007; } \\
\text { 109:84-92 (24) }\end{array}$ & Retrospective cohort study & 926/ 28 solid malignancies & $\begin{array}{l}\text { Hematologic malignancies } \\
\text { Allogeneic HCT }\end{array}$ & $\begin{array}{l}\text { 10-year cumulative } \\
\text { incidence: } 3.1 \% \text {; } \\
1.85 \text {-fold increased } \\
\text { risk compared with } \\
\text { general population; } \\
\text { Older age at HCT and } \\
\text { female donor } \\
\text { associated with } \\
\text { increased risk }\end{array}$ \\
\hline $\begin{array}{l}\text { Socie G et al. } \\
\text { Blood 1991; } \\
\text { 78:277-9 (31) }\end{array}$ & Retrospective cohort & $147 / 4$ solid tumors & $\begin{array}{l}\text { Severe aplastic anemia/ } \\
\text { Allogeneic HCT }\end{array}$ & $\begin{array}{l}\text { Cumulative } \\
\text { probability: } 22 \% \text { at } 8 \\
\text { years }\end{array}$ \\
\hline $\begin{array}{l}\text { Socie G et al. J } \\
\text { Clin Oncol 2000; } \\
\text { 18:348-57 (33) }\end{array}$ & Retrospective cohort & $\begin{array}{l}3,182 / 25 \text { solid tumors ; } 20 \\
\text { PTLD }\end{array}$ & Acute leukmia in childhood & $\begin{array}{l}\text { Cumulative risk of } \\
\text { solid tumors : } 11 \% \text { at } \\
15 \text { years; } \\
\text { Age < } 5 \text { years at HCT; } \\
\text { TBI were associated } \\
\text { with increased risk of } \\
\text { solid tumors; chronic } \\
\text { GvHD associated with } \\
\text { decreased risk } \\
\text { Chronic GvHD, } \\
\text { unrelated donor HCT, } \\
\text { T-cell depleted graft, } \\
\text { use of ATG associated } \\
\text { with increased risk of } \\
\text { PTLD. }\end{array}$ \\
\hline $\begin{array}{l}\text { Majhail NS et al. } \\
\text { Blood 2011; } \\
\text { 117:316-22 (35) }\end{array}$ & Retrospective cohort & 4318/ 66 solid cancers & $\begin{array}{l}\text { Acute myeloid leukemia; } \\
\text { Chronic myelogenous } \\
\text { leukemia; } \\
\text { Allogeneic (matched related } \\
\text { and unrelated) HCT }\end{array}$ & $\begin{array}{l}\text { Cumulative incidence: } \\
1.2 \% \text { at } 10 \text { years; } \\
1.4 \text {-fold increased risk } \\
\text { compared with } \\
\text { general population; } \\
\text { Chronic GvHD } \\
\text { associated with } \\
\text { increased risk, sp oral } \\
\text { cavity }\end{array}$ \\
\hline \multicolumn{5}{|c|}{ Specific Second Malignant Neoplasms } \\
\hline $\begin{array}{l}\text { Rowlings PA et al. } \\
\text { J Clin Oncol. } \\
\text { 1999;17:3122- } \\
\text { 3127 (19) }\end{array}$ & Retrospective cohort & $\begin{array}{l}\text { 18,531/ } 8 \text { Hodgkin } \\
\text { lymphoma }\end{array}$ & $\begin{array}{l}\text { Hematologic malignancies, } \\
\text { and severe aplastic anemia } \\
\text { Allogeneic HCT }\end{array}$ & $\begin{array}{l}\text { 6.2-fold increased } \\
\text { risk; } \\
\text { Grade 2-4 acute } \\
\text { GvHD, treatment for } \\
\text { chronic GvHD }\end{array}$ \\
\hline $\begin{array}{l}\text { Leisenring W et al. } \\
\text { J Clin Oncol. } \\
\text { 2006;24:1119- } \\
1126(25)\end{array}$ & $\begin{array}{l}\text { Retrospective cohort study } \\
\text { design }\end{array}$ & $\begin{array}{l}4,180 / 237 \text { non-melanoma } \\
\text { skin cancer }\end{array}$ & $\begin{array}{l}\text { All malignancies and } \\
\text { metabolic disorders } \\
\text { Allogeneic HCT }\end{array}$ & $\begin{array}{l}\text { 20-year cumulative } \\
\text { incidence: } \\
\text { BCC: } 6.5 \% \text {; SCC: } \\
3.4 \% \\
\text { TBI and younger age } \\
\text { at irradiation, light } \\
\text { skin color, chronic } \\
\text { GvHD associated with } \\
\text { BCC } \\
\text { Acute and chronic } \\
\text { GvHD associated with } \\
\text { SCC }\end{array}$ \\
\hline $\begin{array}{l}\text { Curtis RE et al. } \\
\text { Blood 2005; } \\
\text { 105:3802-11 (34) }\end{array}$ & Case-control & $\begin{array}{l}58 \text { squamous cell and } 125 \\
\text { basal cell carcinomas; } \\
501 \text { matched controls }\end{array}$ & $\begin{array}{l}\text { Hematologic malignancies, } \\
\text { severe aplastic anemia, } \\
\text { hemoglobinopathies; } \\
\text { Allogeneic (matched related } \\
\text { and unrelated) HCT }\end{array}$ & $\begin{array}{l}\text { Prolonged and severe } \\
\text { chronic GvHD and its } \\
\text { therapy (azathioprine, } \\
\text { corticosteroids, } \\
\text { cyclosporine) were }\end{array}$ \\
\hline
\end{tabular}




\begin{tabular}{|c|c|c|c|c|}
\hline Study & Study design & $\begin{array}{l}\text { Sample size/ number of } \\
\text { SMNs }\end{array}$ & $\begin{array}{l}\text { Primary Diagnoses; Type } \\
\text { of HCT }\end{array}$ & $\begin{array}{l}\text { Magnitude of Risk } \\
\text { and Risk Factors }\end{array}$ \\
\hline & & & & $\begin{array}{l}\text { associated with } \\
\text { squamous cell } \\
\text { carcinomas }\end{array}$ \\
\hline $\begin{array}{l}\text { Schwartz JL et al. } \\
\text { Radiat Res. } \\
\text { 2009;171:155-163 } \\
(36)\end{array}$ & Retrospective Cohort & $\begin{array}{l}6,306 / 282 \text { Basal cell } \\
\text { carcinomas }\end{array}$ & $\begin{array}{l}\text { Hematologic malignancies; } \\
\text { severe aplastic anemia; } \\
\text { Autologous, matched related } \\
\text { and unrelated donor HCT }\end{array}$ & $\begin{array}{l}\text { TBI exposure; } \\
\text { youngest age at HCT; } \\
\text { Increasing attained } \\
\text { age; whites; more } \\
\text { recent birth cohorts }\end{array}$ \\
\hline $\begin{array}{l}\text { Friedman DL et al. } \\
\text { Blood. } \\
\text { 2008;111:939-944 } \\
\text { (5) }\end{array}$ & Retrospective cohort study & $\begin{array}{l}3337 \text { females/ } 52 \text { breast } \\
\text { cancers }\end{array}$ & $\begin{array}{l}\text { Hematologic malignancies } \\
\text { Allogeneic HCT }\end{array}$ & $\begin{array}{l}\text { Cumulative incidence } \\
11 \% \text { at } 25 \text { years; } \\
\text { Longer time since } \\
\text { HCT, use of TBI, } \\
\text { younger age at } \mathrm{HCT}\end{array}$ \\
\hline $\begin{array}{l}\text { Cohen A et al. J } \\
\text { Clin Oncol. } \\
\text { 2007;25:2449- } \\
2454(6)\end{array}$ & Retrospective cohort study & $78,914 / 32$ thyroid cancer & $\begin{array}{l}\text { All malignancies and severe } \\
\text { aplastic anemia } \\
\text { Autologous and allogeneic }\end{array}$ & $\begin{array}{l}\text { 3.26-fold increased } \\
\text { risk } \\
\text { Young age at HCT, } \\
\text { irradiation, female } \\
\text { sex, chronic GvHD }\end{array}$ \\
\hline
\end{tabular}

